This item was submitted to Loughborough's Research Repository by the author.

Items in Figshare are protected by copyright, with all rights reserved, unless otherwise indicated.

\title{
Irrigation distribution networks' vulnerability to climate change
}

PLEASE CITE THE PUBLISHED VERSION

http://ascelibrary.aip.org/dbt/dbt.jsp?KEY=JIDEDH\&Volume=136

PUBLISHER

(C) ASCE

VERSION

AM (Accepted Manuscript)

LICENCE

CC BY-NC-ND 4.0

REPOSITORY RECORD

Urrestarazu, Luis Perez, lan K. Smout, J.A. Rodriguez Diaz, and M.T. Carrillo Cobo. 2019. "Irrigation Distribution Networks' Vulnerability to Climate Change". figshare. https://hdl.handle.net/2134/6449. 
This item was submitted to Loughborough's Institutional Repository (https://dspace.lboro.ac.uk/) by the author and is made available under the following Creative Commons Licence conditions.

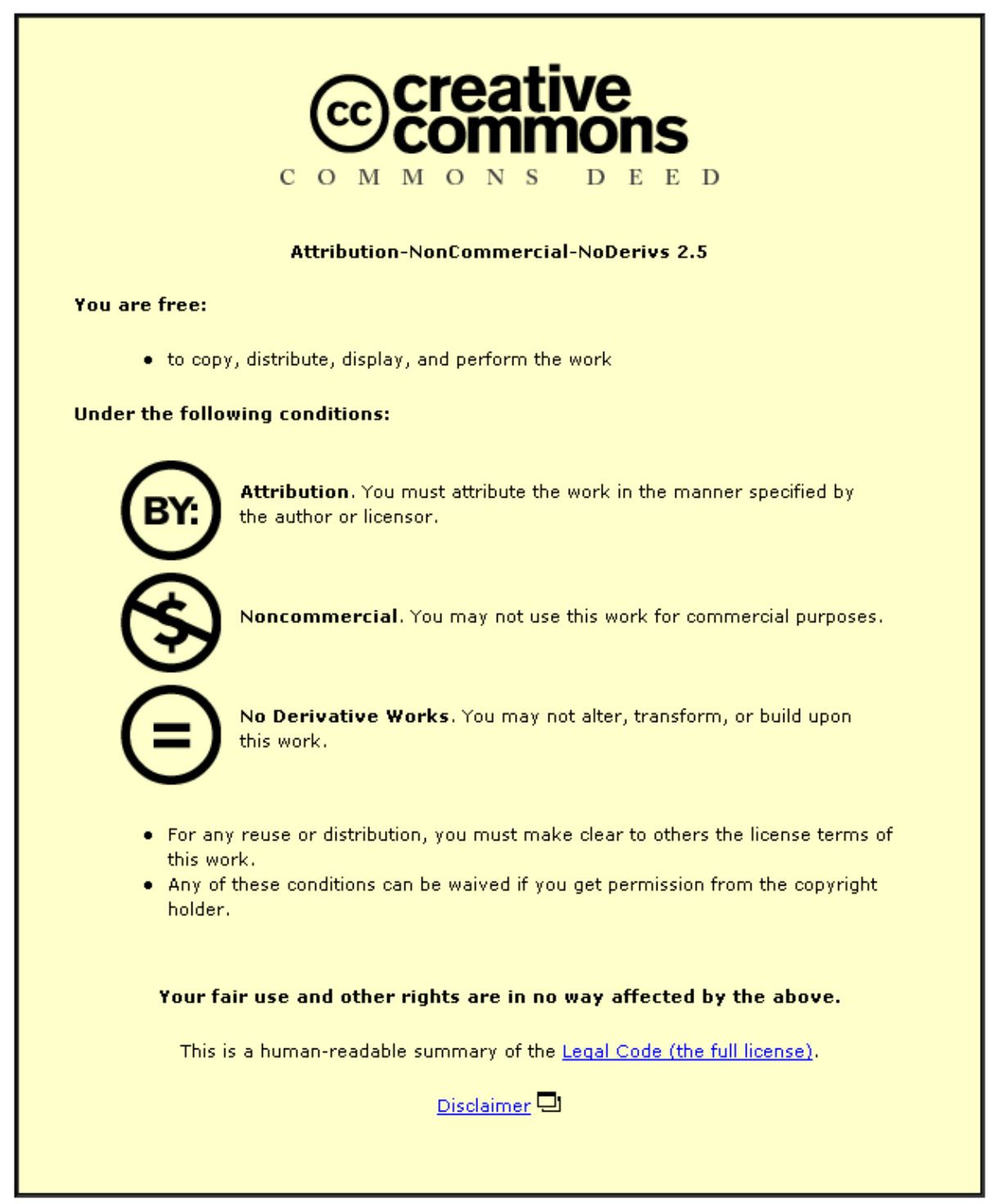

For the full text of this licence, please go to: http://creativecommons.org/licenses/by-nc-nd/2.5/ 


\title{
IRRIGATION DISTRIBUTION NETWORKS’ VULNERABILITY TO CLIMATE CHANGE
}

\author{
Pérez Urrestarazu, L. ${ }^{1}$; Smout, I. K. ${ }^{2}$; Rodríguez Díaz, J. A. ${ }^{3}$; Carrillo Cobo, M.T. ${ }^{4}$
}

\begin{abstract}
Climate change will lead to changed demands on existing irrigation systems. This paper presents a methodology for investigating the performance of irrigation networks under climate change, and applies this to an irrigation network in Cordoba, southern Spain. The methodology uses emission scenarios (A2 and B2) developed by the Intergovernmental Panel on Climate Change. A global climate model (HadCM3) is used with downscaling to predict climate variables for 2050 and 2080 under the emission scenarios. European agricultural policy scenarios are used to predict future cropping patterns. Irrigation water requirements are then estimated for various combinations of these climate and cropping pattern scenarios, and the performance of the irrigation network is evaluated in terms of the equity and adequacy of pressure at the outlets, using EPANET. The methodology was applied to the Fuente Palmera irrigation district, which supplies water on-demand for drip irrigation. The results show that climate change would have a major impact on network performance with the existing cropping pattern, but that expected changes in cropping pattern would reduce this impact.
\end{abstract}

\footnotetext{
${ }^{1}$ Professor. Area of Agro-forestry engineering. University of Seville. EUITA Ctra. Utrera km.1, 41013. Sevilla. Spain (corresponding author). E-mail: lperez@us.es

${ }^{2}$ Principal Programme Manager. Water, Engineering and Development Centre, Loughborough University, Leicestershire, LE11 3TU, UK. E-mail: i.k.smout@lboro.ac.uk

${ }^{3}$ Research Fellow. Department of Agronomy. University of Córdoba. Campus Rabanales, Edif. Da Vinci, 14071. Córdoba. Spain. E-mail: ma2rodij@uco.es

${ }^{4}$ Research Fellow. Department of Agronomy. University of Córdoba. Campus Rabanales, Edif. Da Vinci, 14071. Córdoba. Spain. E-mail: g22carco@uco.es
} 


\section{CE Database subject headings: Climatic changes; Water distribution systems; Hydraulic networks}

\section{Introduction and background}

The future is characterized by uncertainty and change. In the agriculture sector, there are multiple factors which capture the dominant dimensions of this change. Some of them can be classified as independent external drivers such as macro-economic factors, agricultural trade and policy, and consumers and markets. Others might be secondary drivers such as rural development and agroenvironmental policy, the structure of farming and farmer motivation (Morris et al. 2005). But in the longer term, the potential significant effect of climate change is nowadays recognised worldwide. The impact of climate and global socio-economic change will depend on environmental conditions as well as the capacity to adapt to change.

Vulnerability assessment is an increasingly significant aspect of research on impacts and adaptation to climate variability and change. The water resources sector, in coping with current climate variability and anticipating future vulnerabilities to climate changes, represents an important example of the challenges that come with integrating multiple elements in a vulnerability assessment (Dow et al. 2007). Because of the predicted reduction in available water resources (Iglesias et al. 2005), the change in annual distribution of rainfall (Moreno 2005) and in crop water requirements (Mínguez et al. 2005), there will be an impact on the performance of irrigation systems. They will have to be designed for longer and higher peaks in irrigation water demand which may cause problems in some of the networks already working (Rodríguez Díaz et al. 2007a). These uncertainties as to how irrigation systems will have to adapt to these changes are issues that water authorities are compelled to 
address (De Wrachien and Ragab 2004). In practice, changes in technology are likely to reduce or outweigh the impact of climate change in addition to some measures to promote adaptation as improvement of water use efficiency, appropriate water pricing, management and technology in irrigated areas (FAO 2002).

At the present time, climate change impact on agriculture has become a recurrent issue and many studies have been done (Rosenzweig et al. 1995; Cuculeanu et al. 1999; Guereña et al. 2001; Parry et al. 2004; Tubiello and Fischer 2007; Meza et al. 2008), some of them related to impact on irrigation (Allen et al. 1991; McCabe and Wolock 1992; Doll 2002; De Silva et al. 2007; Fischer et al. 2007; Rodríguez Díaz et al. 2007a; Yano et al. 2007). However, the effect on irrigation distribution networks has not been tackled. Therefore, the main objective of this paper is the study of the vulnerability of irrigation systems to climate change. With this purpose a methodology to assess the possible effects of future changes on irrigation networks has been developed and applied in Fuente Palmera irrigation district (Spain).

\section{Climate and socio-economic change scenarios}

A common approach to studying changes in global situation over the time is to attempt to define a number of possible futures, called scenarios. Long-term scenarios are an indispensable tool for the assessment of major uncertainties as well as of the consequences of alternative policy actions for global challenges, ranging from the implications of resource depletion to environmental issues such as climate change (Grübler et al. 2007). Abildtrup et al. (2006) describe a procedure for defining such scenarios for agriculture in terms of population, economic, technical, climate and social changes. The IPCC (Intergovernmental Panel on Climate Change) published a set of scenarios in 2000 for use in the Third Assessment Report (Special Report on Emissions Scenarios - SRES). The SRES scenarios were constructed to explore future developments in the global environment with special reference to the production of greenhouse gases and aerosol precursor emissions.Their starting point was four narrative 
storylines, describing different ways in which the world population, economics, technology, and (nonclimate) policies may evolve over the coming decades. These storylines provide a framework within which to develop socio-economic scenarios as a basis for impact, adaptation and vulnerability assessments (Arnell et al. 2004). Therefore, four SRES storylines represent different world futures, which describe the ways in which global population, economies and non-climate policies may evolve over the coming decades. Even though the storylines occupy a multidimensional space and no simple metric can be used to classify them, it has been useful to describe the scenarios using two-dimensional space. The first dimension designates a more economic (A scenarios) or a more environmental (B scenarios) orientation and the second dimension a more global (1) or a more regional (2) orientation. Accordingly, the storylines are termed A1, A2, B1, and B2 (Nakicenovic et al. 2000):

1. A1: a future world of very rapid economic growth, global population that peaks in midcentury and declines thereafter, and rapid introduction of new and more efficient technologies.

2. A2: a very heterogeneous world with continuously increasing global population and regionally oriented economic growth that is more fragmented and slower than in other storylines.

3. B1: a convergent world with the same global population as in the A1 storyline but with rapid changes in economic structures toward a service and information economy, with reductions in material intensity, and the introduction of clean and resource-efficient technologies.

4. B2: a world in which the emphasis is on local solutions to economic, social, and environmental sustainability, with continuously increasing population (lower than A2) and intermediate economic development.

For this study, A2 and B2 scenarios were considered intending to bracket the most salient scenario variables of demographic and economic development at the high and the intermediate side (scenarios 
A2 and B2 respectively) (Grübler et al. 2007). The B2 scenario can be considered as an intermediary scenario, characterized by 'dynamics as usual' rates of change (Riahi et al. 2007).

The publication of the special report on emission scenarios, the so-called SRES scenarios, facilitated the development of socio-economic scenarios that are consistent with the emission scenarios used as input in the climate models. Future agricultural and water scenarios concerning water policy (WFD) and the Common Agricultural Policy (CAP) were developed in the WADI (WAter Demand Integration) project which focused on changes in EU agricultural and water policy affecting economic, social and environmental performance of irrigation in the European partner countries (Bazzani et al. 2005). Hence, four Foresight type scenarios were created in the WADI project and linked to agricultural policy scenarios (Morris and Vasileiou 2003):

- World Markets (WM) are characterised by an emphasis on private consumption and a highly developed and integrated world trading system.

- Global Sustainability (GS) is characterised by more pronounced social and ecological values, which are evident in global institutions and trading systems. There is collective action to address social and environmental issues. Growth is slower but more equitably distributed compared to the World Markets scenario.

- Provincial Enterprise (PE) is characterised by emphasis on private consumption but with decisions made at national and regional level to reflect local priorities and interests. Although market values dominate, this is within national/regional boundaries.

- Local Stewardship (LS) is characterised by strong local or regional governments which emphasise social values, encouraging self-reliance, self sufficiency and conservation of natural resources and the environment.

Linking with the SRES framework then allows the climate and socio-economic scenarios to be combined in an internally consistent way, as the underpinning socio-economic assumptions drive greenhouse gas emissions and therefore climate change. Where a climate change scenario was coupled 
with its corresponding socio-economic scenario, these are given as A1+WM, A2+PE, B1+GS and B2+LS (Audsley et al. 2006).

\section{Predictions on future cropping patterns}

Any holistic overview of future crop yields must consider all aspects of environmental and socioeconomic changes (Huntingford et al. 2005). Changes in crop sown areas are explained as a function of the driving factors determining the crop utilities, which influence the crop choices of those involved (Rounsevell et al. 2005; Wu et al. 2007). In general, these driving factors include biophysical factors (e.g. temperature, rainfall, soil physicochemical properties and topography) (Gobin et al. 2002), demographic factors (e.g. rural population density), socio-economic factors (e.g. farming income per capita, agricultural mechanization, road accessibility and international trade price) (Müller and Zeller 2002) and technological factors (e.g. irrigation, fertilizers and pesticides). For this reason, it is difficult to make predictions on possible cropping patterns in the future. There are few studies to determine future crop distributions and some organizations have tried to give an overview of global tendencies in agriculture (FAO 2003). Gill et al. (2006) presented a more regional-oriented research about the potential distribution of bioenergy crops in Europe based on the SRES scenarios. They predict a decline in maize and wheat especially in Spain and increase of olive trees and sunflower. Berbel et al. (2005) present possible future cropping patterns in the Guadalquivir basin in Spain, taking into account the WADI scenarios.

\section{Methodology}

Predicting a future situation is always difficult, and even more when there are so many influencing variables. This study considers changes in climate variables and in crop patterns. Climate change data derived from the Had-CM3 Global Climate Model (GCM) has been used. The HadCM3 is a coupled 
Atmosphere-Ocean General Circulation Model (AOGCM) developed at the Hadley Centre for Climate Prediction and Research (Gordon et al. 2000; Pope et al. 2000). This model has a spatial resolution of $2.5^{\circ} \times 3.75^{\circ}$ (latitude by longitude); this produces a grid of $72 \times 96$ cells, resulting in a grid resolution of $280 \mathrm{~km} \mathrm{x} 320 \mathrm{~km}$ across Spain. In order to provide information on possible changes in global climate, the GCM is forced to consider future scenarios where elevated levels of atmospheric CO2 concentration are assumed depending on differing levels of anthropogenic activity. This information is given by the SRES scenarios already described. For reducing the pixel size, the changes predicted by the HadCM3 model must be applied to a more detailed 'baseline' climatology. This is a 10' latitude/longitude dataset containing mean monthly surface climate over global land areas, excluding Antarctica, for the period 1961-1990 (New et al. 2002). The SRES scenarios have been used to generate perturbed climatic datasets in this baseline for future defined time periods. Using krigging interpolation techniques, the relative changes predicted by the HadCM3 model for precipitation, solar radiation, wind speed and relative humidity have been applied to the baseline values for each pixel in the study area. For temperature absolute values were computed instead of relative changes. This methodology has already been applied for downscaling climate datasets by de Silva et al. (2007) and Rodríguez Díaz et al. (2007a). However, the baseline and HadCM3 climate change datasets do not contain reference evapotranspiration $\left(\mathrm{ET}_{0}\right)$ values; a technique developed by Hess and Knox (2003) was therefore used to calculate mean monthly $\mathrm{ET}_{0}$ for each pixel for the baseline and each future SRES scenario. For this procedure, the FAO Penman-Monteith equation was used to calculate $\mathrm{ET}_{0}$ for each grid pixel, since this has been recognised as the international standard method of ET estimation (Smith 2000).

Once the future climate variables are obtained, Figure 1 shows the methodology applied. In order to foresee crop patterns, the SRES scenarios have been used in addition with the WADI Agricultural Policy scenarios. Three time horizons have been selected: the baseline, constructed as an average of data from 1996 to 2007; and the projected years 2050 and 2080 as future situations. Therefore rainfall and $\mathrm{ET}_{0}$ data were obtained for baseline, A2 2050, B2 2050, A2 2080 and B2 2080 for a case study irrigation district in southern Spain. Crop patterns for baseline, A2+PE and B2+LS have been 
produced using the trends of crop areas from 1996 to 2007 and the available studies on crop predictions (FAO 2003; Berbel et al. 2005; Gill et al. 2006).

Figure 1. Flow chart showing methodology

CROPWAT model (Clarke et al. 1998) was applied to obtain crop water requirements, irrigation requirements and maximum flow required using the rainfall and $\mathrm{ET}_{0}$ data and the crop patterns estimated for each scenario. This model has already been applied to determine the impacts of potential climate change on daily and total crop water requirements (Doria et al. 2006) in conjunction with the climate change scenarios. The irrigation network has been modelled in EPANET (Figure 2), one of the most widespread hydraulic simulation models. EPANET was developed by EPA's Water Supply and Water Resources Division and it performs extended-period simulation of the hydraulic and water quality behavior within pressurized pipe networks (Rossman 2000). The inputs are the topology and characteristics of the network, the demand pattern in an average day and the maximum flows required in each outlet obtained from the CROPWAT model. After running the simulations in all the situations (baseline, A2 2050, B2 2050, A2 2080 and B2 2080), key variables are obtained for calculating selected indicators as described below.

Figure 2. Model of the network in EPANET for the baseline

\section{Methodology constraints}

The main limitation of this methodology is the scale effect within the climate change model, since HadCM3 provides a bigger scale than the smaller baseline, interpolation techniques have been used. This interpolation may distort the results. Anyway, as long as regional models take as inputs the outputs of the GCM, the general trends in irrigation requirements are supposed to be very similar. Also, this research has been done for an average year and interannual variability can aggravate the situation. Actually, more frequent droughts are predicted, what could have an even stronger impact on water resources availability, irrigation requirements and therefore on irrigation water demand (European Environment Agency 2007). The analyses described here have considered only one GCM 
(HadCM3) and only two SRES scenarios. The climate change model can have significant influence on the results mostly after the mid-century where predicted impacts under different socioeconomic scenarios start to diverge significantly (Hadley Centre 2005). For example, the ECHAM4 scenario predicts a warmer but wetter climate, which makes the increases in global irrigation requirements for the entire world approximately 50\% smaller than under the HadCM3 scenario (Doll 2002). Also water resources availability may considerably differ from one GCM to others (Arnell, 2004). The methodology necessarily assumes that crop practices are unchanged, ignoring the adaptations that will inevitably occur. Although they are based in previous analysis where many factors were taken into account, crop pattern predictions may be also inaccurate due to the general uncertainty about policy, market and farmer decisions trends in the future.

\section{Network performance}

Neri (1998) established that the global performance of an irrigation system comes from how the service responds to farmer's requirements, taking into account the limits imposed by policies and the resource availability. So when designing or managing an irrigation system, the main constraint is that the required flows should be supplied to water users with adequate pressure (Farmani et al. 2007). For that reason, changes in these required flows due to increase of demand because of climate change could affect the whole performance of the network. Cropping patterns are highly influenced by the ability of the system to avoid uncontrolled situations of water stress, especially for high value crops (Clemmens and Molden 2007), so flexibility of service in the network is needed to cope with the changes in farmers' requirements.

In on demand systems, the farmer has water available whenever he wants so the limitations on irrigation depend on the given flow and pressure in the outlets. If the system is overloaded, farmers may be obliged to cut off the supply and postpone irrigation (Rodríguez Díaz et al. 2007b). Therefore, these systems require a higher distribution capacity which makes them much more expensive (Alandi 
et al. 2001). Errors in the estimation of the future demand may lead to lower quality in the provided service. Hence, this is a new challenge for service quality in irrigation water distribution systems and it is essential to have information of the future network performance.

In order to study the future behavior of the network, two performance indicators are used. Each indicator is a quantitative measure of an aspect of irrigation performance standards which helps to evaluate and monitor irrigation (Alegre et al. 2000). They are ratios that relate variables in such a way that a large amount of information can be reduced to a single number (Rodríguez Díaz et al. 2008).

\section{Pressure equity (PEq)}

This indicator represents how pressure is distributed between outlets in the network using the Interquartile ratio (Abernethy 1986; Bird 1991; Bhutta and Van der Velde 1992; Bos et al. 1994; Gorantiwar and Smout 2005):

$$
\mathrm{PEq}=\frac{\overline{\mathrm{P}_{\mathrm{pq}}}}{\overline{\mathrm{P}_{\mathrm{bq}}}}
$$

where $\overline{\mathrm{P}_{\mathrm{pq}}}$ is the average pressure in the poorest quarter and $\overline{\mathrm{P}_{\mathrm{bq}}}$ is the average pressure in the best quarter, taking into account all the network's checkpoints.

2. Simulated/assigned pressure ratio ( $\left.\mathrm{P}_{\mathrm{s} / \mathrm{a}}\right)$ (Pérez Urrestarazu et al. 2009)

This indicator the pressure obtained in the simulations with the one assigned in the outlets (Pérez Urrestarazu 2007):

$$
\left(\mathrm{P}_{\mathrm{s} / \mathrm{a}}\right)_{i}=\left(\frac{\mathrm{P}_{\mathrm{s}}}{\mathrm{P}_{\mathrm{a}}}\right)_{i}
$$

where $\mathrm{P}_{\mathrm{s}}$ is the simulated pressure measured in the checkpoint and $\mathrm{P}_{\mathrm{a}}$ is the design pressure in the $i$ checkpoint. When $\mathrm{P}_{\mathrm{s} / \mathrm{a}}<1$, it means that this outlet will be working below the required pressure.

In addition, the values of maximum pumped flow and power requirements are determined. 


\section{Irrigation district description}

This methodology has been implemented in Fuente Palmera, an irrigation district located in Cordoba (southern Spain) in the Guadalquivir river basin (Figure 3). In this basin, increases of around $16-20 \%$ in the crop water requirements are predicted by the 2050s due to climate change. The irrigation seasons are also predicted to be longer than at present due to the lower rainfall in April to June (Rodríguez Díaz et al., 2007a).

Figure 3. Fuente Palmera irrigation district location

Fuente Palmera irrigation district has 5611 ha with 85 group of fields or sectors devoted to a wide range of crops (mainly citruses, cereals and olive trees). It is covered by a well-maintained pressurized network designed to provide irrigation on demand. In recent years, the distribution system was upgraded, improving the network and changing the main irrigation method from sprinkler to drip irrigation. The water is taken from the Guadalquivir river and pumped thanks to a pumping station with a maximum flow capacity of $6 \mathrm{~m}^{3} / \mathrm{s}$ giving pressure to the system. The main network is formed by $37992 \mathrm{~m}$ of pipes and is able to supply $1.2 \mathrm{l} / \mathrm{s} / \mathrm{ha}$ on demand in each one of the 85 outlets. The assigned pressure in the outlet is $30 \mathrm{~m}$.

\section{Results and discussion}

Climate variables have been calculated for Fuente Palmera irrigation district zone. Compared to the baseline, both A2 and B2 scenarios show major differences in rainfall and $\mathrm{ET}_{0}$ (Figure 4) in 2050 and $2080 . \mathrm{ET}_{0}$ is around $14 \%$ higher than baseline by the 2050 s and $25 \%$ by the 2080 s. The increase of $\mathrm{ET}_{0}$ is higher in winter for $\mathrm{A} 2$ scenarios though in $\mathrm{B} 2$ the increments are more constant along the year. July has the most unfavorable situation in all the scenarios. Rainfall will decrease by $11 \%$ on average 
by the 2050s, specially in spring and summer months, and by $20 \%$ and $35 \%$ for B2 and A2 respectively by the 2080s. Increased rainfall is predicted in some months of winter. Overall, the situation will be more unfavorable as in the months with peak demand, the conditions will be more extreme (less rainfall and more $\mathrm{ET}_{0}$ ).

Figure 4. Values of rainfall and $E T_{0}$ for all the scenarios

Figure 5 shows the evolution of crop patterns from 1996 to 2007 and the prediction for A2+PE and B2+LS scenarios. Citrus and olive tree areas maintain their increasing trend and become the most important crops in the district though in B2+LS the area of olive trees decreases a bit. Cotton and sunflower areas have a decreasing trend being really low in A2+PE. Maize areas will continue reducing as in recent years and wheat will do the same after the high peak in 2007. Fruit trees will experience the biggest increase. The area destined to set-aside will be higher in both scenarios. Table 1 presents the percentages of area for each crop in Baseline, A2+PE and B2+LS introduced in the CROPWAT model.

Figure 5. Evolution of crop patterns in Fuente Palmera irrigation district

In order to calculate requirements in CROPWAT, nine situations have been taken into account:

- baseline

- changed cropping patterns with no climate change (CC) (using baseline climate variables and A2+PE and B2+LS scenarios for crop patterns),

- changed cropping patterns with CC in 2050 and 2080 (both scenarios)

- CC (both scenarios) without cropping pattern changes (CPC) which means using the same crop pattern as for the baseline.

Figure 6 shows the annual values for crop water requirements (CWR), irrigation requirements (IR) and maximum flow of water supply (FWS) for the mentioned situations (note that baseline is represented as no CC and no CPC). CWR are higher than baseline in all cases increasing around $30 \%$ 
in A2+PE and B2+LS and $14 \%$ with no CPC by the 2050s. By the 2080s, CWR will be 21, 41 and 46 \% higher than baseline for no CPC, A2+PE and B2+LS respectively. Differences between A2+PE and B2+LS are relatively small (20-30 mm). IR for A2+PE and B2+LS with no CC are nearly the same as baseline and FWS in these two situations is even lower than baseline which means that the crop combination in these cases has lower flow requirements in the peak period. IR are $25-35 \%$ higher by the 2050 s and up to $50-60 \%$ by the 2080 s.

In the case of maximum FWS, there are more differences between scenarios which is important because FWS is the key factor affecting the network performance. By the 2050s, FWS values for A2+PE are only $3.5 \%$ higher than baseline, being for B2+LS $10 \%$ higher. By the 2080s, results show an increase of $15 \%$ over baseline in A2+PE and nearly $25 \%$ for B2+LS. It should be highlighted that FWS values in case of no CPC are higher than in A2+PE and B2+LS scenarios as they increase 33 and $45 \%$ over baseline by the 2050s and 2080s respectively. This means that due to the crop distribution, requirements for the different crops are more concentrated in certain periods for baseline crop pattern (though CWR and IR are lower during the year). FWS with no CPC is even higher by the 2050s than in B2+LS scenario by the 2080s so the crop pattern can be even more important than CC in the variations of FWS. When no CPC is taken in account, there is not much difference between A2 and B2 SRES scenarios so only one was used to calculate FWS in this case.

Figure 6. CWR, IR and FWS for all the situations

The nine situations mentioned above were simulated in the network model created with EPANET for a peak demand reference day using the maximum flow required in the outlets (given by the FWS CROPWAT parameter and the area supplied) for each scenario. The demand pattern was also modeled and all the information about the parameters of the network was achieved hourly for this twenty-four hours period. Data on flows, pressures and power requirements were obtained. Table 2 shows the average values of the indicators and variables calculated for a reference day. The change in pressures is in a range of $2 \mathrm{~m}$ higher or lower than baseline which means that pressure will not be much affected 
in the future in $\mathrm{A} 2+\mathrm{PE}$ and $\mathrm{B} 2+\mathrm{LS}$ scenarios though in case of no CPC, pressure could decrease $5 \mathrm{~m}$ which could affect the most unfavorable outlets. PEq and $\mathrm{P}_{\mathrm{s} / \mathrm{a}}$ values are very similar to baseline by the 2050s and will be a bit lower by the 2080s when the number of outlets with $\mathrm{P}_{\mathrm{s} / \mathrm{a}}<1$ will increase between 30 and $53 \%$ over the baseline. That means that in B2+LS 2080, seven outlets more will work under the assigned pressure. Again, if no CPC is taken into account, PEq decreases 11 and $19 \%$ by the 2050s and 2080s respectively and the number of outlets with $\mathrm{P}_{\mathrm{s} / \mathrm{a}}<1$ is significantly higher. When no CC is taken into account $\mathrm{A} 2+\mathrm{PE}$ and $\mathrm{B} 2+\mathrm{LS}$ would need less pumping capacity due to lower maximum pumped flow required being consistent with the lower flow requirements discussed above. In the 2050s it is slightly higher, specially for B2+LS scenario (nearly $5 \%$ over baseline) and by the 2080s the required pumping capacity increases $13.4 \%$ in $\mathrm{A} 2+\mathrm{PE}$ and $18 \%$ in B2+LS. Power requirements will be similar by the 2050s but will be increased around $13 \%$ in the 2080s. With no CPC, maximum flow required would be $34 \%$ higher than baseline by the 2050 s and $46 \%$ by the 2080s and power requirements would be increased up to $38 \%$ by the 2080s. Therefore, results clearly point out how climate change would have a major impact on network performance with the existing cropping pattern, but that expected changes in cropping pattern would reduce this impact.

Table 1. Average values of the indicators and variables calculated for a reference day

\section{Conclusions}

Because of the projected change in climatic conditions in the Cordoba region of southern Spain, the irrigation requirements will be higher in 2050 and 2080, leading to the increase of maximum flow requirements in the pumping station and in the outlet. That means that many networks will be overloaded and improvements in the infrastructures will be required to cope with this raising demand. This general conclusion is valid for various climatic scenarios and projected copping patterns.

In the case of Fuente Palmera irrigation district, the system would still work properly in these conditions because it was designed for sprinkler irrigation so the pumping capacity is very high. 
However both water consumption and power requirements would be higher. The big changes in CWR or IR do not have much effect on the network performance in terms of pressure at least in the 2050s though the influence is slightly higher by the 2080s. The pumping capacity required is more difficult to satisfy in both situations.

Changes in crop pattern were proved to have high influence in network performance, even more than climate change. Therefore, the increase of network requirements expected due to climate change predictions can be reduced using an appropriate crop pattern, adjusting CWR during the year and avoiding the concentration of the water demand in a peak period. The good selection of crops and the adaptation of varieties to new climate conditions could be the key factors to prevent network capacity overload.

Besides, there is not much difference between the SRES and WADI scenarios considered either in terms of requirements or network performance. This means that whatever the evolution in policies and socio-economic patterns is, the impact on network performance will be low, compared to the global impact of climate and cropping pattern change.

In addition, the methodology presented in this paper will help to identify the network areas which could have problems in the future and to assess other irrigation districts with different characteristics.

\section{Acknowledgements}

The development of this paper has been possible thanks to the Spanish national program of human research resources relocation (Jose Castillejo grant, Plan Nacional de I-D+I 2008-2011). 


\section{List of symbols}

CC: Climate Change

CPC: Crop Pattern Changes

CWR: Crop Water Requirements

IR: Irrigation Requirements

FWS: Flow Water Supply

GCM: Global Climate Model

GS: Global Sustainability

LS: Local Stewardship

P: real pressure measured in the checkpoint

$\mathrm{P}_{\mathrm{a}}$ : pressure assigned in the checkpoint

$\mathrm{P}_{\mathrm{av}}$ : average pressure

$\mathrm{P}_{\max }$ : maximum pressure

$\mathrm{P}_{\text {min }}:$ minimum pressure

$\mathrm{P}_{\mathrm{s} / \mathrm{a}}$ : simulated/assigned pressure ratio

$\overline{\mathrm{P}_{\mathrm{bq}}}$ : pressure average in the best quarter

$\overline{\mathrm{P}_{\mathrm{pq}}}$ : pressure average in the poorest quarter

PE: Provincial Enterprise

PEq: Pressure Equity

WM: World Markets

\section{References}

Abernethy, C. L. (1986). "Performance Measurement in Canal Water management: A Discussion”. ODI-IIMI Irrigation Management Network Paper 86/2d, pp. 25. 
Abildtrup, J., Audsley, E., Fekete-Farkas, M., Giupponi, C., Gylling, M., Rosato, P., Rounsevell, M.D.A. (2006). "Socio-economic scenario development for the assessment of climate change impacts on agricultural land use”. Environmental Science and Policy, 9 (2), 101-115.

Alandi, P. P., Martín-Benito, J. M. T., Álvarez, J. F. O., Martínez, M. I. C. (2001). “Design of water distribution networks for on-demand irrigation”. Irrigation Science, 20, 189-201.

Allen, R. G., Gichuki, F. N., Rosenzweig, C. (1991). "CO2-Induced Climatic Changes in Irrigation-Water Requirements”. J. Water Resour. Plan. Manage., 117, 157-178.

Audsley, E., Pearn, K.R., Simota, C., Cojocaru, G., Koutsidou, E., Rounsevell, M.D.A., Trnka, M., Alexandrov, V. (2006). "What can scenario modelling tell us about future European scale agricultural land use, and what not?” Environmental Science and Policy, 9 (2), 148-162.

Arnell, N.W. (2004). "Climate change and global water resources: SRES emissions and socioeconomic scenarios”. Global Environmental Change, 14: 31-52

Arnell, N.W., Livermore, M.J.L., Kovats, S., Levy, P.E., Nicholls, R. Parry, M.L., Gaffin, S.R. (2004). "Climate and socio-economic scenarios for global-scale climate change impacts assessments: characterising the SRES storylines”. Global Environmental Change, 14, 3-20.

Bazzani, G.M., Di Pasquale, S., Gallerani, V., Morganti, S., Raggi, M., Viaggi, D. (2005). “The sustainability of irrigated agricultural systems under the Water Framework Directive: first results”. Environmental Modelling and Software, 20, 165-175.

Berbel, J., Jos, M., Gutiérrez, C. (2005). “Impact of Policy Scenarios in Irrigated Agriculture of River Guadalquivir Basin (Southern Spain)”. XI Congress of the EAAE (European Association of Agricultural Economists), The Future of Rural Europe in the Global Agri-Food System, Copenhagen, Denmark.

Bhutta, M. N., Van der Velde, E. J. (1992). "Equity of water distribution along secondary canals in Punjab, Pakistan”. Irrigation and Drainage Systems, 6, 161-177.

Bird, J. D. (1991). "Introducing monitoring and evaluation into main system management - A low investment approach”. Irrigation and Drainage Systems, 5, 43-60. 
Bos, M. G., Murray-Rust, D. H., Merrey, D. J., Johnson, H. G., Snellen, W. B. (1994). "Methodologies for assessing performance of irrigation and drainage Management". Irrigation and Drainage Systems, 7, 231-261.

Clarke, D., Smith, M., El-Askari, K. (1998). “CropWat for Windows: user guide”. FAO, Rome

Clemmens, A. J., Molden, D. J. (2007). "Water uses and productivity of irrigation Systems”. Irrigation Science, 25, 247-261.

Cuculeanu, V., Marica, A., Simota, C., (1999). “Climate change impact on agricultural crops and adaptation options in Romania”. Climate Res., 12, 153-160.

De Silva, C.S., Weatherhead, E.K., Knox J.W., Rodriguez-Diaz, J.A. (2007). “Predicting the impacts of climate change-A case study of paddy irrigation water requirements in Sri Lanka”. Agricultural Water Management, 93 (1-2), 19-29.

De Wrachien,D., Ragab, R. (2004). “Global warming and variability on irrigation requirements in the Mediterranean environment”. Proceedings of the AgEng 2004 Conference on Engineering the Future. Josse De Baerdemaeker. 142-143. AgEng 2004 Conference on Engineering the Future, Leuven ,Belgium.

Doll, P. (2002). “Impact of climate change and variability on irrigation requirements: a global perspective”. Clim. Change, 54, 269-293.

Doria, R. Madramootoo, C.A., Mehdi, B.B. (2006). "Estimation of Future Crop Water Requirements for 2020 and 2050 using CROPWAT”. Engineering Institute of Canada. Climate Change Conference Proceedings. Track 4: Engineering for Adaptation.

Dow, K., O’Connor, R.E., Yarnal, B., Carbone, G.J., Jocoy, C.L.. (2007). “Why worry? Community water system managers' perceptions of climate vulnerability”. Global Environmental Change, 17, 228-237.

European Environment Agency (2007) "Climate change and water adaptation issues”. EEA technical report 2, Copenhagen, Denmark

FAO (Food and Agriculture Organization) (2002). "World agriculture: towards 2015/30, Summary report”. Food and Agriculture Organization of the United Nations. Rome. 
FAO (Food and Agriculture Organization) (2003). “World agriculture: towards 2015/30, An FAO perspective”. Food and Agriculture Organization of the United Nations. Rome.

Farmani, R., Abadia, R., Savic, D. (2007). “Optimum Design and Management of Pressurized Branched Irrigation Networks”. J. Irrig. Drain. Eng., 133 (6), 528-537.

Fischer, G., Tubiello, F.N., van Velthuizen, H., Wiberg, D.A. (2007). "Climate change impacts on irrigation water requirements: Effects of mitigation, 1990-2080". Technological Forecasting and Social Change, 74, 1083-1107.

Gill, T., Glendining, M. J., Smith, P., House, J. I., Wattenbach, M. (2006). “The potential distribution of bioenergy crops in Europe under present and future climate”. Biomass and Bioenergy, 30, 183-197.

Gobin, A., Campling, P., Feyen, J. (2002). "Logistic modelling to derive agricultural land use determinants: a case study from southeastern Nigeria”. Agric. Ecosyst. Environ., 89, 213-228.

Gorantiwar, S. D., Smout, I. K. (2005). "Performance assessment of irrigation water management of heterogeneous irritation schemes: 1. A framework for evaluation”. Irrigation and Drainage Systems, 19, 1-36.

Gordon, C., Cooper, C., Senior, C.A., Banks, H., Gregory, J.M., Johns, T.C., Mitchell, J.F.B., Wood, R.A. (2000). “The simulation of SST, sea ice extents and ocean heat transports in a version of the Hadley Centre coupled model without flux adjustments”. Clim Dyn, 16, 147-168.

Grübler, A., O'Neill, B., Riahi, K., Chirkov, V., Goujon, A., Kolp, P., Prommer, I., Scherbov, S., Slentoe, E. (2007). "Regional, national, and spatially explicit scenarios of demographic and economic change based on SRES”. Technological Forecasting and Social Change, 74 (7), 9801029.

Guereña, A., Ruiz-Ramos, M., Díaz-Ambrona, C.H., Conde, J.R., Mínguez, M.I. (2001). “Assessment of climate change and agriculture in Spain using climate models”. Agron. J., 93, 237249.

Hadley Centre (2005). "Climate change and the greenhouse effect. A briefing from the Hadley Centre”. Met Office. UK. 
Hess, T.M., Knox, J.W. (2003). "Deriving evapotranspiration datasets for the UK for use in the climate change modelling”. Internal report, Cranfield University, Silsoe (unpubl), UK.

Huntingford, C., Lambert, F.H., Gash, J.H.C., Taylor, C.M., Challinor, A.J. (2005). “Aspects of climate change prediction relevant to crop productivity”. Phil. Trans. R. Soc. B, 360, 1999-2009.

Iglesias, A., Estrela, T., Gallart, F. (2005). "Impacts on hydric resources. A preliminary general assessment of the impacts in Spain due to the effects of climate change”. Ministerio de Medio Ambiente, Spain.

McCabe, G. J. and Wolock, D. M. (1992). "Sensitivity of Irrigation Demand in a HumidTemperate Region to Hypothetical Climatic Change”. Water Resour. Bull. Amer. Water Resour. Assoc., 28, 535-543.

Meza, F., Silva, D., Vigil, J. (2008). "Climate change impacts on irrigated maize in Mediterranean climates: Evaluation of double cropping as an emerging adaptation alternative". Agricultural Systems, 98, 21-30.

Mínguez, I., Ruiz, A., Estrada A. (2005). "Impacts on the agrarian sector. A preliminary general assessment of the impacts in Spain due to the effects of climate change”. Ministerio de Medio Ambiente, Spain.

Moreno, J.M. (2005). “Evaluación preliminar de los impactos en España por efecto del cambio climático”. Ministerio de Medio Ambiente, Spain.

Morris, J., Vasileiou, K. (2003). "Future of agricultural irrigated systems in Europe: future scenarios of the CAP”. Wadi document n.D4. Institute of Water and Environment, UK., 22 pp.

Morris, J., Audsley, E., Wright, I.A., McLeod, J., Pearn, K., Angus, A., Rickard, S. (2005). “Agricultural Futures and Implications for the Environment”. Main Report and Supporting Appendices. Defra Research Project IS0209. Bedford: Cranfield University.

Müller, D., Zeller, M. (2002). "Land use dynamics in the central highlands of Vietnam: a spatial model combining village survey data with satellite imagery interpretation”. Agric. Econ., 27, 333-354.

Nakicenovic, N., Alcamo, J., Davis, G., de Vries, B, Fenhann, J., Gaffin, S., Gregory, K., Grübler, A., Yong Jung, T., Kram, T., Lebre La Rovere, E., Michaelis, L., Mori, S., Morita, T., 
Pepper, W., Pitcher, H., Price, L., Riahi, K., Roehrl, A., Rogner, H., Sankovski, A., Schlesinger, M., Shukla, P., Smith, S., Swart, R., van Rooijen, S., Victor, N. and Dadi, Z. (2000). "Special Report on Emissions Scenarios”. Special Report of Working Group III of the Intergovernmental Panel on Climate Change, Cambridge University Press, Cambridge, U.K., 599 pp.

New, M., Lister, D., Hulme, M., Makin, I. (2002). “A high resolution data set of surface climate over global land areas”. Clim Res, 21, 1-25.

Neri, L. (1998). “Considerazioni su alcuni indicatoi di prestazione dei sistemi irrigui”. Rivista di Irrigazione e Drenaggio, 45, 61-65.

Parry, M.L., Rosenzweig, C., Iglesias, A., Livermore, M., Fischer, G. (2004). "Effects of climate change on global food production under SRES emissions and socio-economic scenarios”. Global Environmental Change, 14 (1), 53-67.

Pérez Urrestarazu, L. (2007). “Aplicación de los indicadores para el análisis de las acciones de mejora en zonas regables y para el desarrollo de un modelo de gestión integral del agua de riego”. Ph.D. Thesis. University of Cordoba.

Pérez Urrestarazu, L., Rodríguez Díaz, J. A., Camacho Poyato, E., López Luque, R. (2009). "Quality of service in irrigation distribution networks - the case of Palos de la Frontera irrigation district (Spain)”. J. Irrig. Drain. Eng., doi:10.1061/(ASCE)IR.1943-4774.0000107.

Pope, V.D., Gallani, M.L., Rowntree, P.R., Stratton, R.A (2000). “The impact of new physical parametrizations in the Hadley Centre climate model: HadAM3”. Clim Dyn, 16,123-146.

Riahi, K., Grübler, A., Nakicenovic, N. (2007). "Scenarios of long-term socio-economic and environmental development under climate stabilization”. Technological Forecasting and Social Change, 74 (7), 887-935.

Rodríguez Díaz, J.A., Weatherhead, E. K., Knox , J. W., Camacho, E. (2007a.) “Climate change impacts on irrigation water requirements in the Guadalquivir river basin in Spain". Regional Environmental Change, 7, 149-159.

Rodríguez Díaz, J. A., Camacho Poyato, E., López Luque, R. (2007b). “Model to Forecast Maximum Flows in On-Demand Irrigation Distribution Networks”. J. Irrig. Drain. Eng., 133 (3), 222-231. 
Rodríguez Díaz, J. A., Camacho Poyato, E., López Luque, R., Pérez Urrestarazu, L. (2008). "Benchmarking and multivariate data analysis techniques for improving the efficiency of irrigation districts: An application in Spain”. Agricultural systems, 96, 250-259.

Rosenzweig, C., Allen , L. H., Harper, L. A., Hollinger, S. E., Jones, J. W. (1995). “Climate change and agriculture: analysis of potential international impacts”. ASA Special Publication 59. Madison, WI: ASA, CSSA and SSSA.

Rossman, L. (2000). “EPANET 2. Users Manual”. United States Environmental Protection Agency.

Rounsevell, M.D.A., Ewert, F., Reginster, I., Leemans, R., Carter, T.R. (2005). “Future scenarios of European agricultural land use. II. Projecting changes in cropland and grassland”. Agriculture, Ecosystems and Environment, 107, 117-135.

Smith, M. (2000). "The application of climatic data for planning and management of sustainable rain-fed and irrigated crop production”. Agric For Meteorol, 103, 99-108.

Tubiello, F.N., Fischer, G. (2007). "Reducing climate change impacts on agriculture: Global and regional effects of mitigation, 2000-2080”. Technological Forecasting and Social Change, 74 (7), 1030-1056.

Yano, T., Aydin, M., Haraguchi, T. (2007). “Impact of Climate Change on Irrigation Demand and Crop Growth in a Mediterranean Environment of Turkey”. Sensors, 7, 2297-2315.

Wu W., Shibasaki R., Yang P., Tan G., Matsumura K.I., Sugimoto K. (2007). “Global-scale modelling of future changes in sown areas of major crops”. Ecological Modelling, 208 (2-4), 378390. 
Table 1. Average values of the indicators and variables calculated for a peak demand reference day

\begin{tabular}{|c|c|c|c|c|c|c|c|c|c|c|}
\hline & & \multirow{2}{*}{\multicolumn{3}{|c|}{ No CC }} & \multirow{2}{*}{\multicolumn{3}{|c|}{2050}} & \multirow{2}{*}{\multicolumn{3}{|c|}{2080}} \\
\hline & & & & & & & & & & \\
\hline & & Baseline & $\mathrm{A} 2+\mathrm{PE}$ & $\mathrm{B} 2+\mathrm{LS}$ & $\mathrm{A} 2+\mathrm{PE}$ & $\mathrm{B} 2+\mathrm{LS}$ & No CPC & $\mathrm{A} 2+\mathrm{PE}$ & $\mathrm{B} 2+\mathrm{LS}$ & No CPC \\
\hline \multirow{3}{*}{ Pressure (m) } & Max & 89.17 & 90.11 & 90.97 & 89.04 & 88.60 & 81.91 & 87.48 & 86.85 & 82.69 \\
\hline & Min & 12.20 & 14.99 & 13.48 & 12.08 & 11.74 & 9.89 & 10.93 & 10.46 & 7.44 \\
\hline & Av & 45.45 & 47.69 & 46.86 & 45.33 & 44.94 & 40.95 & 44.05 & 43.52 & 40.03 \\
\hline \multicolumn{2}{|l|}{ Pressure Equity (Peq) } & 0.37 & 0.40 & 0.39 & 0.37 & 0.36 & 0.33 & 0.35 & 0.34 & 0.30 \\
\hline \multirow{3}{*}{$\begin{array}{l}\text { Simulated/assigned } \\
\text { pressure ratio (Ps/a) }\end{array}$} & Max & 2.97 & 3.00 & 3.03 & 2.97 & 2.95 & 2.73 & 2.92 & 2.89 & 2.76 \\
\hline & Min & 0.41 & 0.50 & 0.45 & 0.40 & 0.39 & 0.33 & 0.36 & 0.35 & 0.25 \\
\hline & Av & 1.51 & 1.59 & 1.56 & 1.51 & 1.50 & 1.37 & 1.47 & 1.45 & 1.33 \\
\hline \multicolumn{2}{|l|}{ Outlets with Ps/a $<1$} & 13 & 9 & 11 & 13 & 13 & 25 & 17 & 20 & 27 \\
\hline \multicolumn{2}{|c|}{ Max pumped flow $\left(\mathrm{m}^{3} / \mathrm{s}\right)$} & 3.01 & 2.34 & 2.56 & 3.05 & 3.16 & 4.05 & 3.42 & 3.56 & 4.42 \\
\hline \multicolumn{2}{|c|}{ Power requirements (kW) } & 1962.79 & 1587.48 & 1646.63 & 1968.65 & 2035.93 & 2508.57 & 2240.04 & 2217.52 & 2711.71 \\
\hline
\end{tabular}




\section{LIST OF TABLES}

Table 1. Average values of the indicators and variables calculated for a reference day

\section{LIST OF FIGURES}

Figure 1. Flow chart showing methodology

Figure 2. Model of the network in EPANET for the baseline

Figure 3. Fuente Palmera irrigation district location, within Cordoba Region

Figure 4. Values of rainfall and $E T_{0}$ for all the scenarios

Figure 5. Evolution of crop patterns in Fuente Palmera irrigation district

Figure 6. CWR, IR and FWS for all the situations 


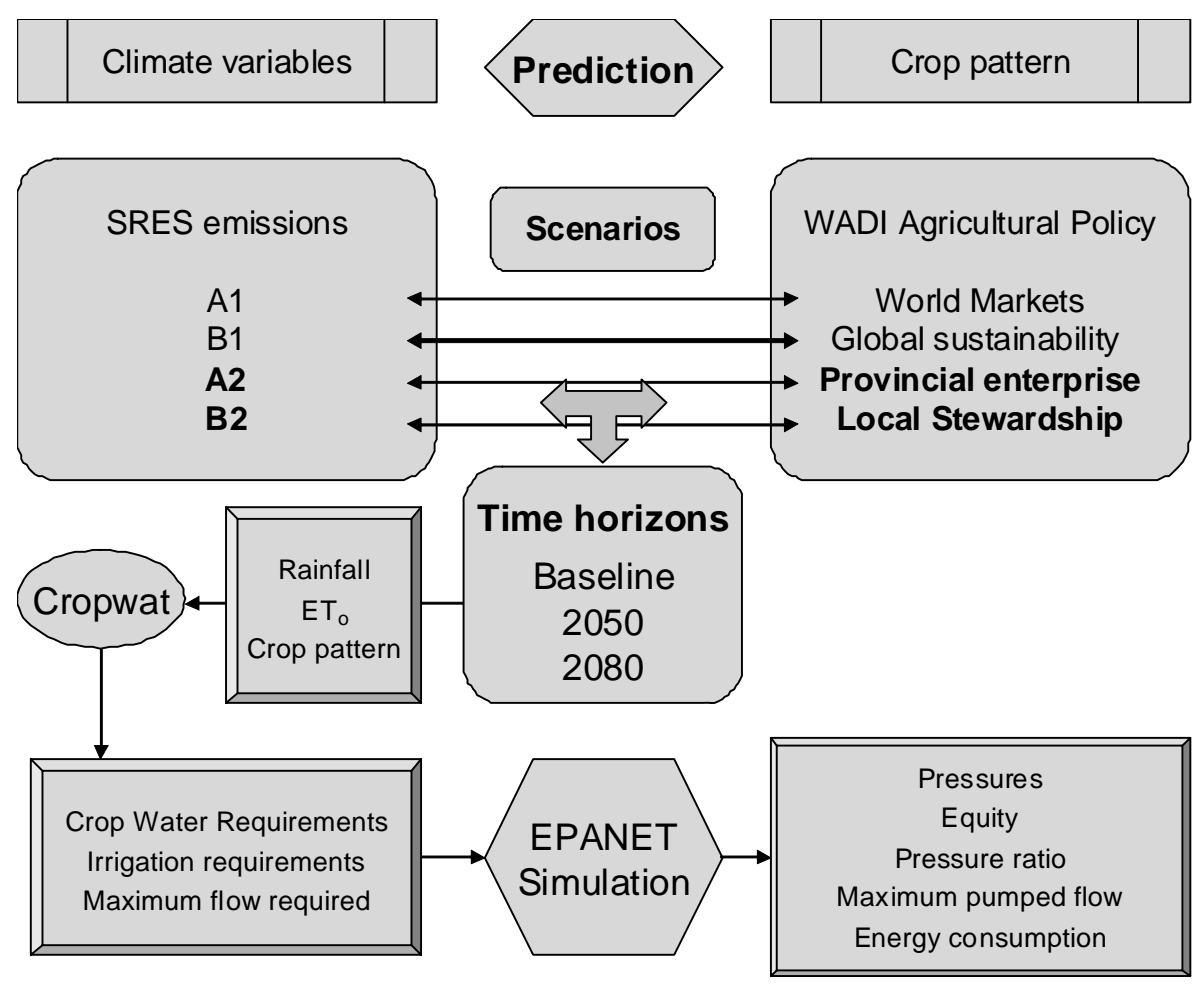

Figure 1. Flow chart showing methodology 


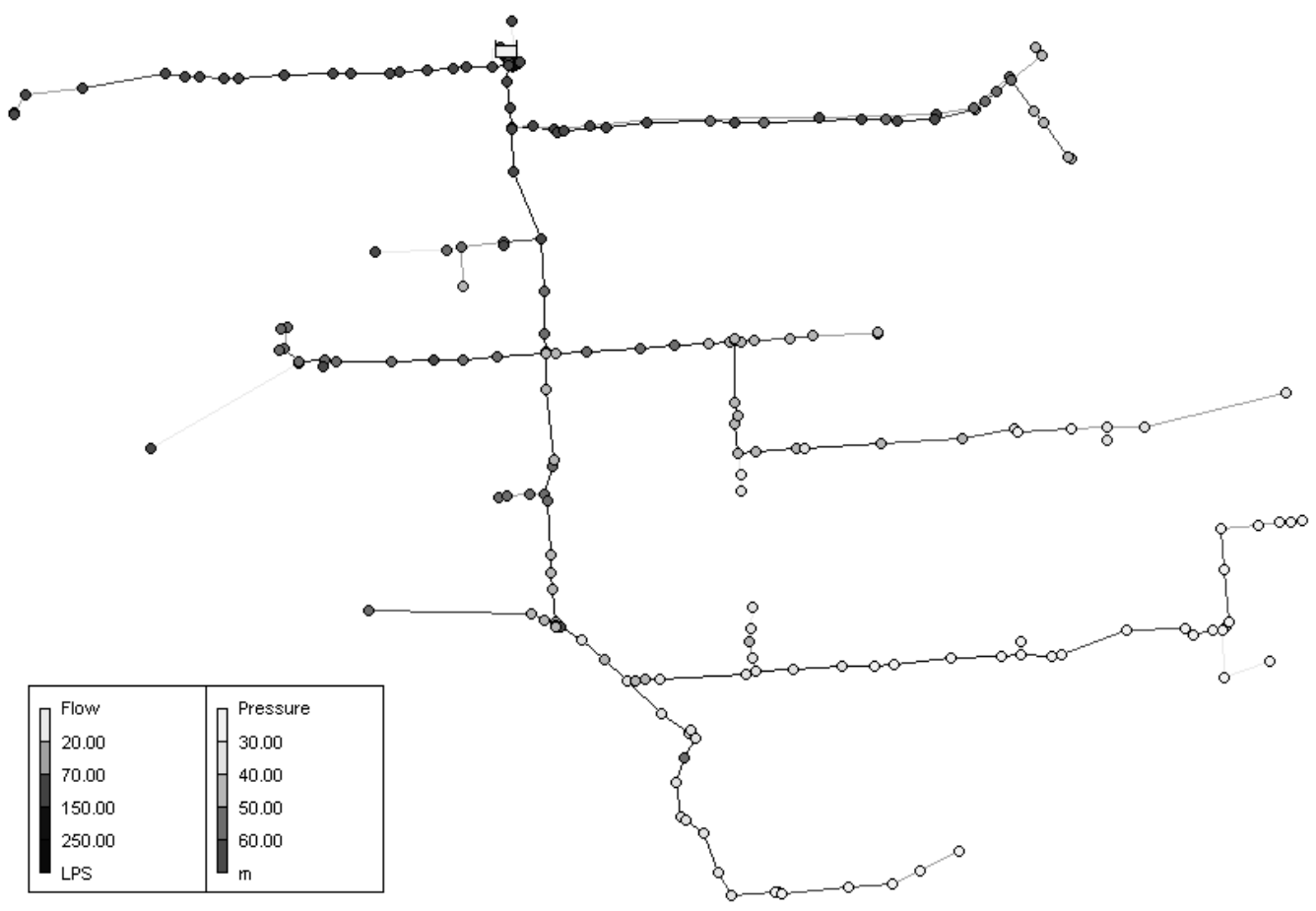

Figure 2. Model of the network in EPANET for the baseline 


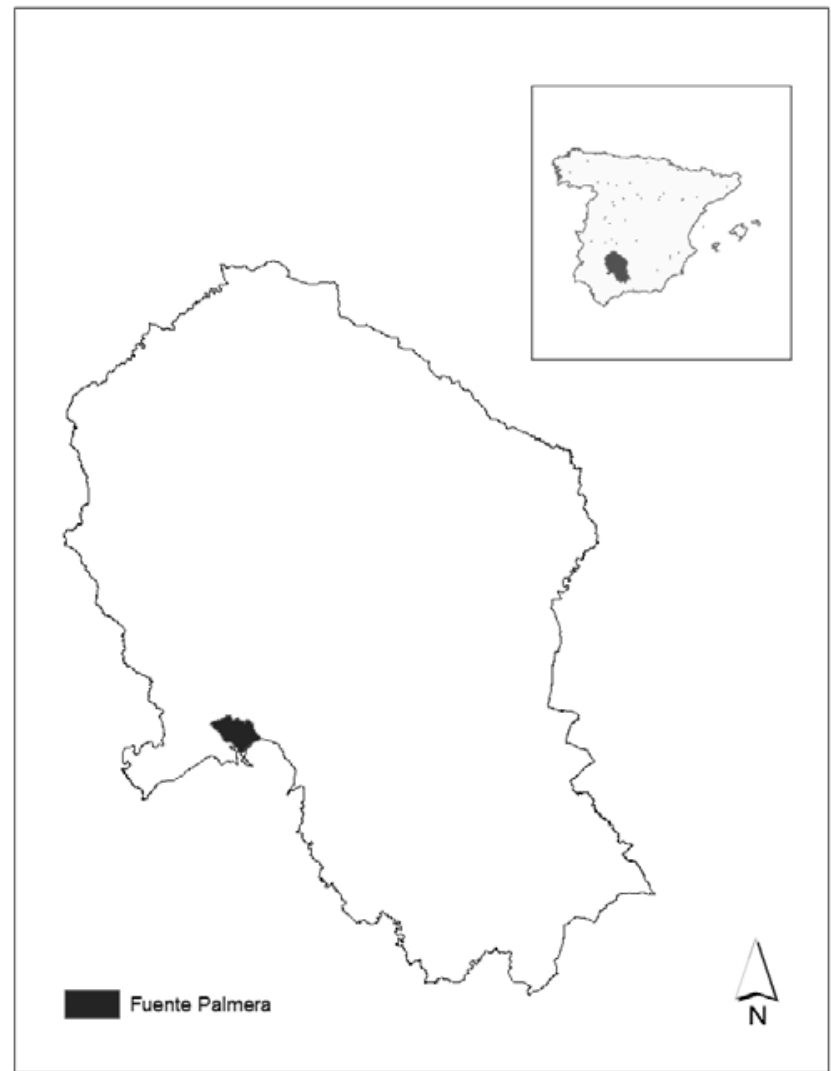

Figure 3. Fuente Palmera irrigation district location, within Cordoba Region 


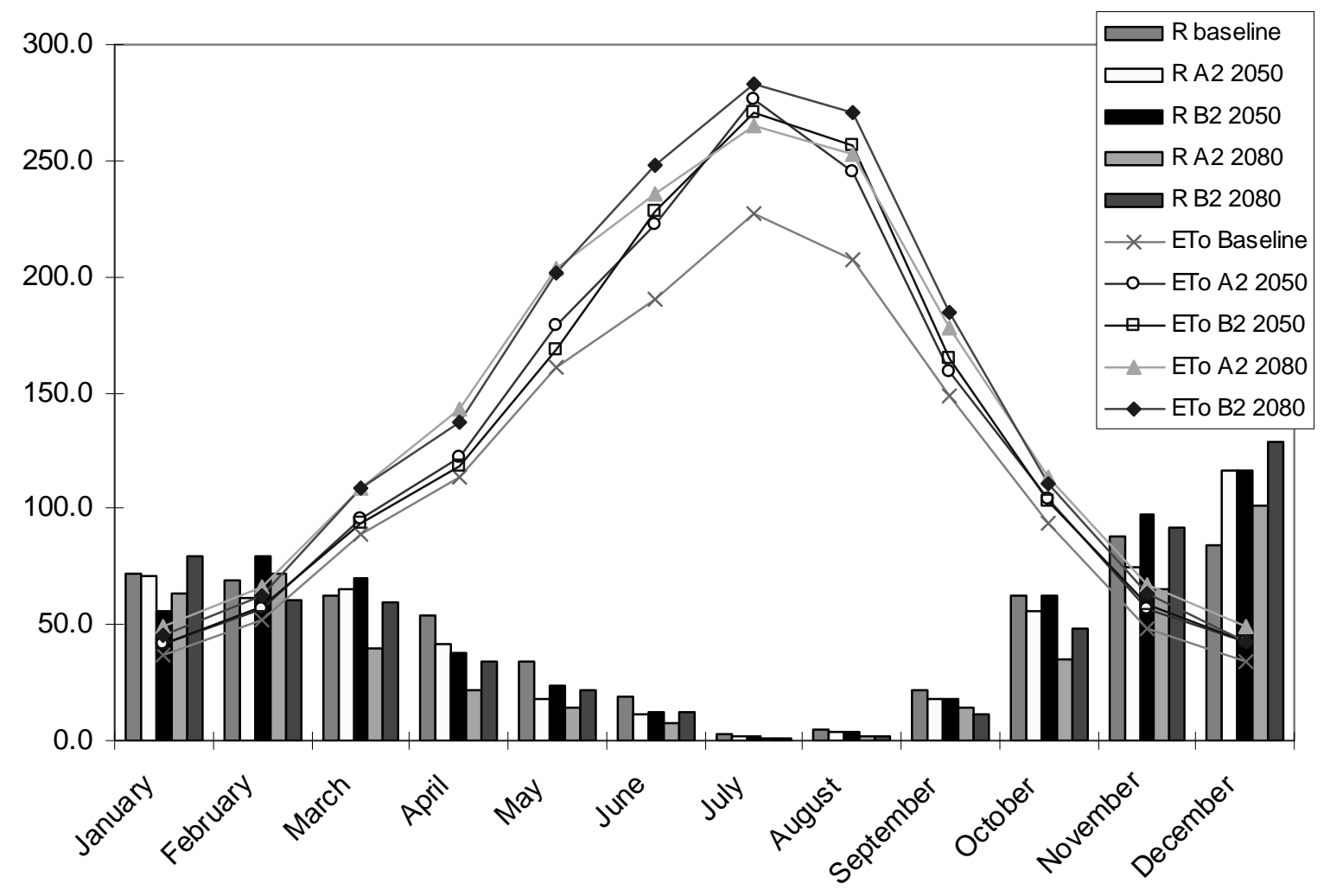

Figure 4. Values of rainfall and $E T_{0}$ for all the scenarios 


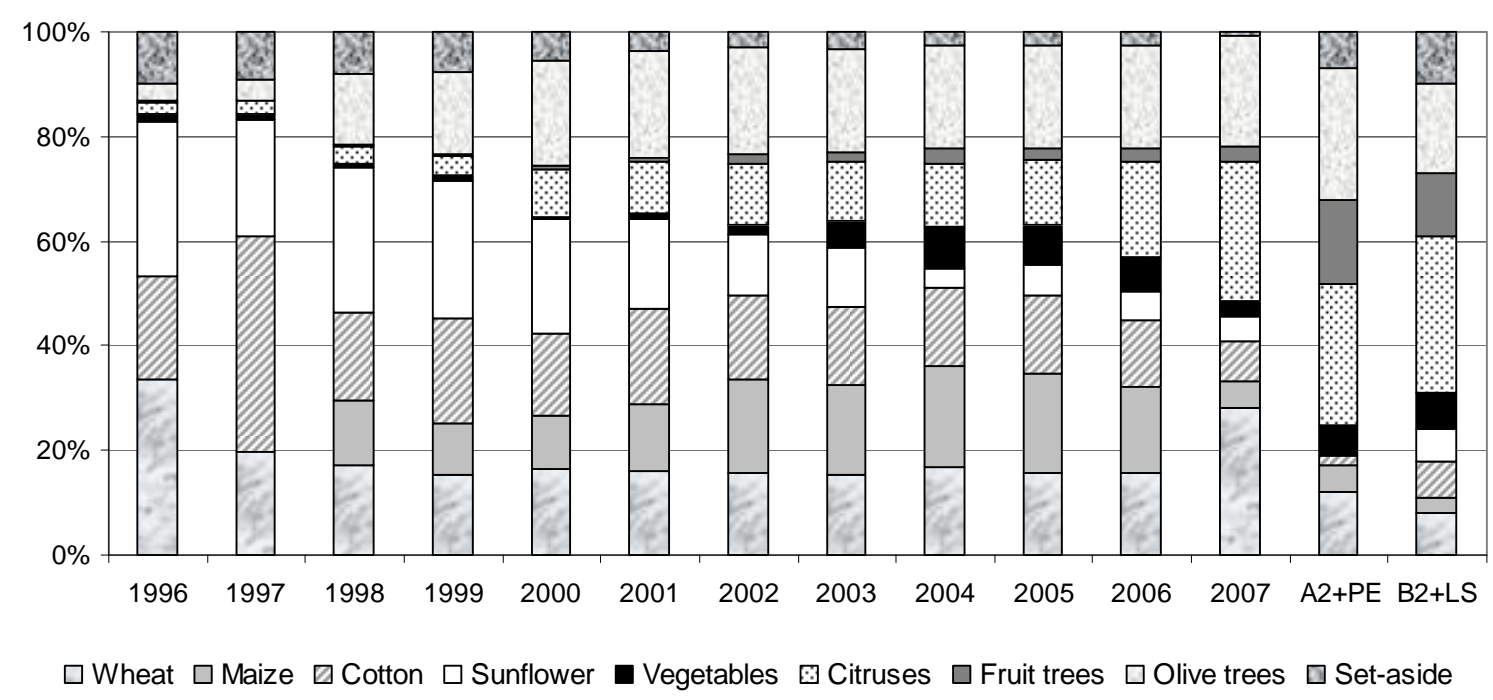

Figure 5. Evolution of crop patterns in Fuente Palmera irrigation district 

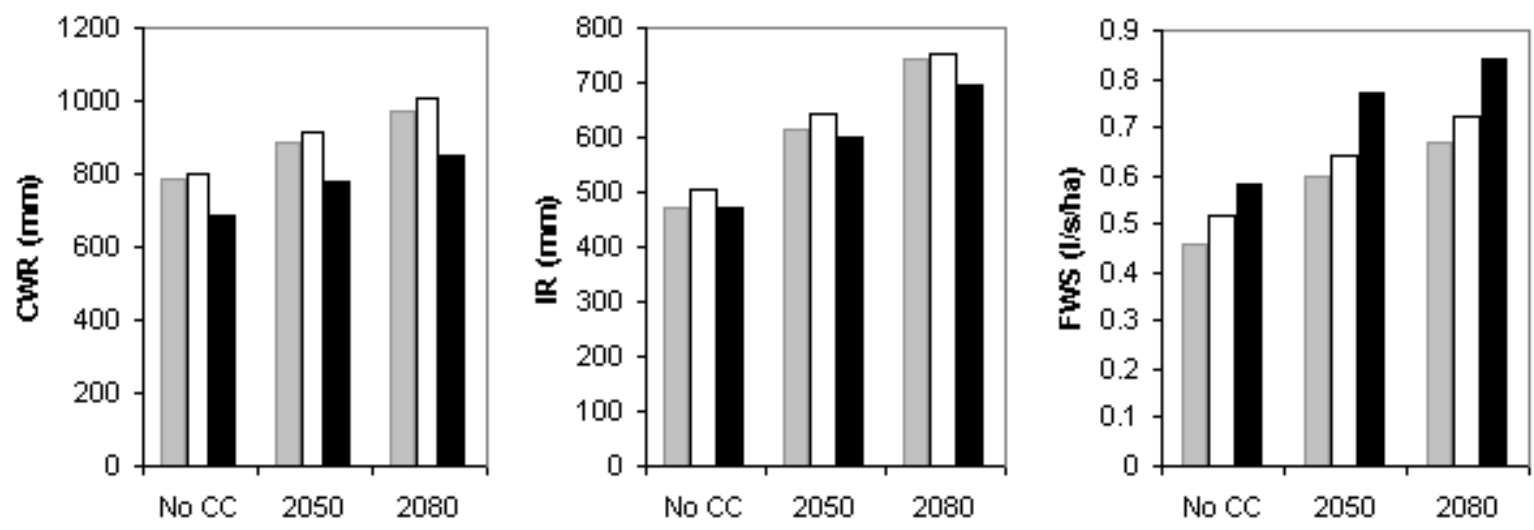

Scenario $\square \mathrm{A} 2+\mathrm{PE} \quad \square \mathrm{B} 2+\mathrm{LS} \square$ No $\mathrm{CPC}$

Figure 6. CWR, IR and FWS for all the situations 